Fidei: Jurnal Teologi Sistematika dan Praktika, Vol. 4, No. 1, Juni 2021

Fidei: Jurnal Teologi Sistematika dan Praktika

Terakreditasi No: 85/M/KPT/2020 (Sinta 4)

e-ISSN: $2621-8135$

http://www.stt-tawangmangu.ac.id/e-journal/index.php/fidei

Vol. 4 No.1 (Juni 2021) hlm: 1-23

p-ISSN: 2621-8151

DOI: https://doi.org/10.34081/fidei.v4i1.225

\title{
Sikap Gereja Menghadapi Kekerasan Terhadap Perempuan Upaya Mereduksi Pelanggaran HAM
}

\author{
Dwi Ratna Kusumaningdyah, Arif Wicaksono ${ }^{1}$ )" \\ $\left.{ }^{1}\right)$ Sekolah Tinggi Teologi Tawangmangu, Indonesia \\ *) Email: dwiratna1965@gmail.com
}

Diterima: 17 Feb. 2021

Direvisi: 27 Apr. 2021

Disetujui: 19 Mei 2021

\begin{abstract}
Abstrak
Kekerasan terhadap perempuan telah menjadi bagian dari $\mathrm{s}$ ejarah manusia. Akibatnya terjadi tindakan diskriminatif terhadap perempuan dan hal ini menempatkan perempuan dalam posisi subordinasi jika diperhadapkan dengan kedudukan seorang laki-laki dalam struktur kemasyarakatan. Menghadapi situasi seperti ini, acap kali gereja tidak mengungkapkan suara keadilan untuk menyejajarkan posisi perempuan dengan laki-laki. Jika diskursus ini dilihat dalam kerangka hak azasi manusia, maka hal ini dapat dipandang sebagai bentuk pelanggaran hak azasi manusia karena kedudukan perempuan telah didegradasi dari hakikatnya yang sejajar dengan laki-laki. Artikel ini hendak menyoroti tentang kekerasan yang dialami oleh perempuan sebagai bentuk pelanggaran hak azasi manusia. Dengan menggunakan metode fenomenologi yang dilengkapi dengan analisis dan interpretasi tekstual terhadap beberapa bagian Alkitab, dihasilkan sebuah rekomendasi bagi gereja untuk bertindak dalam menyuarakan keadilan bagi perempuan. Gereja harus menjadi pendamping dan sekaligus menjadi agen perubahan terhadap tindakan kekerasan bagi perempuan, yang merupakan bagian langsung dari pelanggaran hak azasi manusia.
\end{abstract}

Kata-Kata Kunci: Gereja; Hak Azasi Manusia; Kekerasan; Perempuan. 


\section{Abstract}

Violence against women has become a part of human history. As a result, there is discriminatory action against women and this places women in a subordinate position when faced with the position of a man in the social structure. Faced with this kind of situation, the church often does not express the voice of justice to align the position of women with men. If this discourse is seen in the framework of human rights, then this can be seen as a violation of human rights because the position of women has been degraded from being equal to men. This article intends to highlight the violence experienced by women as a form of violation of human rights. By using a phenomenological method that is complemented by textual analysis and interpretation of several parts of the Bible, a recommendation is produced for the church to act in voicing justice for women. The church must be a companion and at the same time an agent of change against acts of violence against women, which are a direct part of human rights violations.

Keywords: Church; Human Rights; Violence; Women.

\section{Pendahuluan}

Pada jaman kerajaan, perempuan dijadikan permaisuri atau selir, bahkan lebih buruk lagi dijadikan budak. Pada masa kolonial, perempuan dijadikan gundik (jugun ianfu) dan pelacur. Semua harus dijalani dalam kepatuhan, karena memberontak berarti mati. ${ }^{1}$ Ketika kapitalisme merambah Indonesia, perempuan menjadi komoditas yang menguntungkan negara, lewat pelacuran dan perdagangan. Lalu Orde Baru berkuasa dan perempuan pun dikurung dalam sangkar "pendamping suami dan ibu yang baik", sementara itu perdagangan perempuan berjalan terus. ${ }^{2}$ Kalau laki-laki hanya bekerja dalam waktu terbatas, perempuan bekerja sepanjang hari untuk waktu yang tak terbatas. Namun upah atau penghargaan dari tenaga yang mereka keluarkan tidak dihitung karena dianggap sebagai sudah seharusnya dilakukan. Hal ini terutama diderita oleh perempuan di sektor pertanian, di pedesaan. Di pasar kerja formal pun perempuan hanya menerima 30-40 persen dari gaji yang diterima laki-laki untuk jenis pekerjaan yang sama, masih ditambah lagi bentuk-bentuk pelecehan terhadap mereka. Tragedi Aceh, tragedi Timor Lorosae, Tragedi Mei 1998 di

\footnotetext{
${ }^{1}$ Israpil Israpil, "Budaya Patriarki Dan Kekerasan Terhadap Perempuan (Sejarah Dan Perkembangannya)," Pusaka 5, no. 2 (2017): 141-150.

2 Toeti Heraty N., "Etika Sosial Dalam Perspektif Jender," in Etika Politik Dalam Konteks Indonesia, ed. Eddy Kristiyanto (Yogyakarta: Kanisius, 2001), 81.
} 
Jakarta memperlihatkan bahwa perempuan menjadi korban konflik politik, yang tidak hanya kehilangan suami dan harta benda, namun juga kehilangan harkat dan martabat karena perkosaan yang dilakukan oleh pihak aparat dan orangorang yang tak bertanggung jawab. ${ }^{3}$

Dalam bilik keluarga juga terdengar jeritan perempuan yang disiksa oleh suami. Ada yang dipaksa melayani meskipun kondisi tidak memungkinkan, dipaksa menandatangani surat cerai karena tak dapat melahirkan keturunan, dipaksa memakai alat kontrasepsi, tidak boleh bekerja di luar rumah, selalu dicurigai dan dituntut mencari nafkah dan mengurus rumah tangga dengan baik. Ada tangis anak perempuan yang diperkosa oleh ayahnya, anak perempuan yang ditipu oleh kekasihnya bahkan ada anak perempuan yang dijual oleh ayahnya sebagai pelacur. ${ }^{4}$ Kenyataan sejarah memperlihatkan bahwa kekerasan terhadap perempuan terjadi di sepanjang masa, bahkan tidak hanya di Indonesia, juga di bagian dunia yang lain. Kekerasan terhadap perempuan merupakan ancaman terhadap semua perempuan setiap hari, tanpa pandang usia, bangsa, agama, status sosial dan dapat dilakukan oleh laki-laki yang mempunyai hubungan dekat ataupun orang asing bahkan pihak penguasa. ${ }^{5}$

Kekerasan terhadap perempuan tidak sekadar terjadi di lingkup domestik dan sosial, bahkan di dalam gereja pun hal ini terjadi. Dalam kehidupan bergereja seringkali ditemui pandangan bahwa kedudukan perempuan, terlebih jika berkaitan dengan masalah pelayanan, ditempatkan dalam posisi yang kurang terhormat; di mana pendapat ini terjadi akibat pandangan tokoh gereja yang bernama Thomas Aquinas, dengan mensitir pendapat Aristoteles mengenai ketidak sempurnaan perempuan sebagai seorang lelaki, yang mengatakan bahwa perempuan tidak layak untuk melayani dalam mimbar-mimbar gereja. ${ }^{6}$ Demikian juga halnya dengan para Reformator (Luther dan Calvin); Luther menegaskan bahwa seorang perempuan tidak mungkin menjadi "Imam Kristus", karena ia sebenarnya adalah "Imam Setan". Sedangkan Calvin mengatakan

${ }^{3}$ Muji Sutrisno, "Beberapa Bingkai Wacana Hak Asasi Manusia Dan Visi Pemerdekaan Perempuan," in Etika Politik Dalam Konteks Indonesia, ed. Eddy Kristiyanto (Yogjakarta: Kanisius, 2001), 103.

${ }^{4}$ Esti Susilarti, "Di Balik Tirai Tabu," in Rifka Annisa, ed. Esti Susilarti (Yogyakarta: SKH Kedaulatan Rakyat dan Rifka Annisa, 2000), 3-5.

${ }^{5}$ Marie M. Fortune, "Violence against Women: The Way Things Are Is Not the Way They Have to Be.," in Sexuality and the Sacred: Sources for Theological Reflection, ed. J.B.Nelson and S.P.Longfellow (Westminster: John Knox Press, 1994), 326-334.

${ }^{6}$ Denise L. Carmody, "Kekristenan Zaman Bapa-Bapa Gereja Dan Abad Pertengahan," in Perubahan Peran Pria Dan Wanita Dalam Gereja Dan Masyarakat, ed. Anne Hommes (Yogyakarta - Jakarta: Kanisius - BPK Gunung Mulia, 1997), 210-211. 
bahwa setiap perempuan Kristen patut tunduk kepada kuasa pria. Hal ini adalah akibat dari kejatuhan manusia ke dalam dosa, sehingga perempuan ditempatkan dalam situasi untuk mengabdi pada perbudakan. ${ }^{7}$

Meskipun suara pembebasan telah diperdengarkan melalui Deklarasi HakHak Asasi Manusia oleh PBB sejak tahun 1948, namun hingga kini nyanyian sunyi dan ratap tangis masih tetap terdengar dari hati dan bibir perempuan. Apakah perempuan tidak punya apa-apa yang layak untuk dihargai atau ia bukan apa-apa dalam kehidupan ini? Apakah ia tak memiliki hak untuk hidup dengan aman dan sejahtera? Di mana Gereja ketika terdengar nyanyian sunyi dan ratap tangis para perempuan? Hal inilah yang menjadi tujuan dari tulisan ini, yaitu untuk memelajari apa yang seharusnya menjadi sikap dan tindakan Gereja, sebagai suatu komunitas iman yang harus berada dan berkarya bersama Tuhan di dalam dunia, dalam menghadapi situasi kekerasan terhadap perempuan yang mengakibatkan munculnya nyanyian-nyanyian sunyi dan ratap tangis para perempuan yang menuntut sebuah pembebasan dari situasi yang menindas.

\section{Metode Penelitian}

Pembahasan dalam artikel ini menggunakan pendekatan fenomenologis, di mana langkah pertama yang penulis lakukan adalah terlebih dahulu mendeskripsikan suatu obyek, fenomena atau setting sosial yang dituangkan dalam tulisan yang bersifat naratif. ${ }^{8}$ Langkah berikutnya, dengan menggunakan metode studi literatur, penulis berusaha mengumpulkan data dari sumbersumber literatur yang berkorelasi dengan masalah dan pokok bahasan untuk dianalisis. Penganalisisan data dilakukan dengan cara memaparkan obyek yang diteliti dalam bentuk uraian narasi untuk diinterpretasi, baik secara budaya, sosial maupun hermeneutik Alkitabiah. Setelah analisis dilakukan terhadap data yang diperoleh dari berbagai sumber literatur, maka disusunlah sebuah kesimpulan dan sekaligus rekomendasi bagi terbentuknya upaya berteologi dalam konteks ketidakadilan gender.

\section{Pembahasan dan Hasil}

\section{Pemahaman tentang Kekerasan Terhadap perempuan}

Untuk memperoleh pemahaman yang jelas tentang kekerasan terhadap perempuan, terlebih dahulu dibahas tentang makna kekerasan. Herkutanto

\footnotetext{
${ }^{7}$ Carmody, "Kekristenan Zaman Bapa-Bapa Gereja Dan Abad Pertengahan."

${ }^{8}$ Albi Anggito and Johan Setiawan, Metodologi Penelitian Kualitatif (Sukabumi: CV Jejak, 2018), 11.
} 
mengungkapkan bahwa kekerasan mempunyai ciri: dapat berupa tindakan fisik maupun nonfisik, dilakukan secara aktif maupun pasif (penelantaran), dikehendaki oleh pelaku dan ada akibat/kemungkinan akibat yang merugikan korban, yang tidak dikehendaki oleh korban. Jadi kekerasan terhadap perempuan adalah tindakan atau sikap yang dilakukan dengan tujuan tertentu sehingga dapat merugikan perempuan baik secara fisik maupun psikis. ${ }^{9}$ Brown mengungkapkan bahwa kekerasan dimengerti sebagai tindakan pelanggaran, pengabaian, penyalahgunaan, penolakan terhadap yang lain, dengan atau tanpa kerugian secara fisik sekalipun. Dan kekerasan tersebut adalah kekerasan terhadap manusia seutuhnya, secara total, jiwa dan raga. Jadi, apapun bentuk kekerasan, hal itu dilakukan terhadap manusia secara total. ${ }^{10}$

Dari pemahaman inilah dapat dilukiskan bahwa kekerasan yang dilakukan terhadap perempuan merupakan kekerasan terhadap diri perempuan seutuhnya, yang meliputi fisik, psikologis dan seksual yang terjadi secara tumpeng tindih pada saat bersamaan. ${ }^{11}$ Sebagai contoh, bila terjadi perkosaan terhadap perempuan, maka bukan hanya penderitaan secara biologis saja yang dialami perempuan, namun seluruh jiwa dan raga, jati diri, harkat dan martabat perempuan itu ternodai.

Kekerasan terhadap perempuan dapat berakibat cedera fisik (dari yang paling ringan hingga yang paling berat), shock, rasa takut, munculnya emosi negatif (marah, perasaan tak berdaya menyalahkan diri sendiri, jijik, malu), depresi, dyspareunia (merasa sakit saat berhubungan seks) atau vaginismus (kekejangan otot-otot vagina) atau syndrom yang lain. ${ }^{12}$ Secara sosial, pada umumnya mereka mengalami keterasingan atau disharmoni dari lingkungannya, baik keluarga maupun masyarakat.

Kekerasan terhadap perempuan pada umumnya terjadi karena: pertama, adanya struktur sosial yang memberikan hak-hak istimewa dan mengutamakan dominasi laki-laki sehingga menempatkan perempuan pada posisi di bawah

${ }^{9}$ Herkutanto, "Kekerasan Terhadap Perempuan Dan Sistem Hukum Pidana, Pendekatan Dari Sudut Pandang Kedokteran," in Penghapusan Diskriminasi Terhadap Wanita, ed. Tapi Omas Ihromi, Sulistyowati Irianto, and A.Sudiarti Luluhima (Bandung: Alumni, 2000), 266267.

${ }^{10}$ R. McAfee Brown, Religion and Violence, 2nd ed. (Philadelphia: The Westminster Press, 1987), 6-7..

${ }^{11}$ Kristi Poerwandari, "Kekerasan Terhadap Perempuan: Tinjauan Psikologi Feministik," in Penghapusan Diskriminasi Trehadap Wanita, ed. Tapi Omas Ihromi, Sulistyowati Irianto, and A.Sudiarti Luluhima (Bandung: Alumni, 2000), 277; Fortune, "Violence against Women: The Way Things Are Is Not the Way They Have to Be."

${ }^{12}$ Poerwandari, "Kekerasan Terhadap Perempuan: Tinjauan Psikologi Feministik." 
(nomor dua) laki-laki. ${ }^{13}$ Kedua, adanya proses internalisasi struktur sosial tersebut di atas, secara terus menerus sehingga mempengaruhi perkembangan/pembentukan karakteristik kepribadian individu (laki-laki terbentuk sebagai individu yang kuat, mendominasi dan perempuan terbentuk sebagai individu yang lemah, tunduk pada laki-laki). Hal ini dapat diperjelas dengan adanya label atau stereotip yang dilekatkan oleh masyarakat pada lakilaki dan perempuan, sehingga pada akhirnya, struktur dan karakter tersebut melestarikan kekerasan terhadap perempuan. ${ }^{14}$

Dari uraian di atas dapat lah disimpulkan bahwa kekerasan terhadap perempuan adalah tindakan yang meniadakan harga diri, martabat, bahkan kemanusiaan manusia perempuan karena perempuan ditempatkan bukan sebagai subyek namun sebagai obyek yang dapat diperlakukan sewenang-wenang. Tindakan kekerasan bukan hanya menimbulkan penderitaan bagi perempuan, namun lebih pada proses dehumanisasi yang dilestarikan. ${ }^{15}$

\section{Pemahaman tentang Hak Asasi Manusia}

\section{Uraian Singkat tentang Lahirnya Deklarasi Hak Asasi Manusia}

Secara umum diakui bahwa gagasan tentang Hak asasi manusia pertama kali dirumuskan oleh John Locke (1632-1704), seorang filsuf liberal pada masa pencerahan, ${ }^{16}$ yang mengatakan bahwa ada hak-hak dasar manusia yang tidak pernah diserahkan kepada negara, itulah yang disebut hak asasi manusia, karena dimiliki sejak manusia dilahirkan, yaitu: hak atas hidup, hak atas kebebasan bergerak dan hak milik pribadi. Hak dasariah tersebut menjadi ciri kemanusiaannya. Gagasan John Locke ini pada akhirnya hanya menguntungkan kelompok masyarakat tertentu.

13 Firman Panjaitan, "Kekerasan Terhadap Istri Dalam Lingkup Domestik (Suatu Tinjauan Etis Kristiani Tentang Kekerasan Terhadap Keluarga)," Fidei: Jurnal Teologi Sistematika dan Praktika 1, no. 1 (2018): 42-67.

${ }^{14}$ Lisa Isherwood and Dorothea McEwan, An A to Z of Feminist Theology (Sheffield: Academic Press, 1996), 230-231; Brown, Religion and Violence.

${ }^{15}$ Kurnia Muhajarah, "Kekerasan Terhadap Perempuan Dalam Rumah Tangga," Sawwa 11, no. 2 (2016).

${ }^{16}$ Bernard T. Adeney-Risakotha, "Reformasi Gereja Dan HAM Orientasi Baru," in Orientasi Baru, Hak Asasi Manusia: Tantangan Bagi Agama (Yogjakarta: Kanisius, 1998), 65; Sutrisno, "Beberapa Bingkai Wacana Hak Asasi Manusia Dan Visi Pemerdekaan Perempuan." 
Salah satu tokoh yang menolak gagasan Locke adalah Stassen, ${ }^{17}$ yang mengungkapkan bahwa pemahaman tersebut terlalu sempit, membingungkan bila diberlakukan di tengah masyarakat yang majemuk dan bertitik tolak dari pandangan sekuler. Lebih lanjut Stassen menjelaskan bahwa dalam kenyataannya gagasan tentang HAM telah lahir pada masa sebelum pencerahan dan Revolusi Perancis, bahkan telah menjadi kehidupan Gereja pada masa revolusi Puritan (abad 16-17), yang menegaskan tentang kebebasan beragama bagi setiap individu. Gagasan ini bertitik tolak dari perjuangan Kristen untuk kebebasan, keadilan dan perdamaian bagi semua manusia. Jadi merupakan pengalaman dan perjuangan yang berangkat dari iman Kristiani. Tokoh yang mempelopori gerakan ini adalah Richard Overton yang membuat pernyataan iman (sebagai landasan tindakan), yaitu seluruh manusia diciptakan dalam Gambar Allah dan Kristus mati untuk semua manusia, Kristus adalah norma bagi Gereja sebagai saksi di tengah masyarakat untuk membela toleransi dan perdamaian. Overton di sepanjang hidupnya telah mengabdikan diri demi tegaknya HAM. ${ }^{18}$ Gagasan tentang HAM tersebar di antara Gereja Baptis, Kongregasionalis, kelompok Bebas dan kaum Puritan dan pada akhirnya John Locke dan para filsuf merumuskannya pada pertengahan abad kemudian. Setelah John Locke merumuskan tentang HAM, pada tahun 1776 muncul cetusan Hak Asasi Virginia yang berbunyi: semua manusia bebas merdeka karena kodratnya, manusia mempunyai hak pokok untuk hidup danb menjalani hidup dengan rasa aman dan bahagia. Tahun 1789, diserukan "Deklarasi HakHak Dasar Manusia dan Hak sebagai warga Masyarakat "di Perancis. Akhirnya pada tanggal 10 Desember 1948 di Paris dicetuskan "Universal Declaration Of Human Rights" oleh PBB. ${ }^{19}$

\section{Tujuan, Perkembangan dan Isi DUHAM (Deklarasi Universal Hak Azasi} Manusia)

Dalam Mukadimah Piagam PBB yang ditandatangani 26 Juni 1945, dituliskan bahwa bangsa-bangsa yang bersatu dalam PBB berketetapan hati agar generasi-generasi mendatang terhindar dari bencana peperangan yang telah dua kali mendatangkan penderitaan bagi umat manusia. Para pendiri kemudian

${ }^{17}$ Douglas Sturm and Glen H. Stassen, Just Peacemaking: Transforming Initiatives for Justice and Peace, Journal of Law and Religion, vol. 16 (Westminster: John Knox Press, 2001), 138.

${ }^{18}$ Ibid.

${ }^{19}$ Sutrisno, "Beberapa Bingkai Wacana Hak Asasi Manusia Dan Visi Pemerdekaan Perempuan." 
memperkuat tekad ini melalui Deklarasi HAM, agar kesetiaan terhadap martabat dan nilai luhur manusia sebagai pribadi benar-benar dilestarikan, baik terhadap laki-laki maupun perempuan, negara besar ataupun negara kecil. Jadi, deklarasi HAM bertujuan untuk meningkatkan penghargaan terhadap HAM serta kebebasan-kebebasan dasar untuk semua orang tanpa pembedaan.

Adapun perkembangan DUHAM, tampak dalam konferensi-konferensi selanjutnya, yaitu: Tahun 1975 , di Mexico, dalam konferensi tersebut PBB membahas tentang Perempuan (dan kekerasan terhadap perempuan) dan pada saat itu juga ditentukan sebagai dekade Wanita (1976-1985) atas usul dan desakan dari berbagai LSM. Tahun 1979, di Wina, PBB mengesahkan konvensi yang bernilai kemanusiaan tinggi yaitu Elimination of All Forms of Discrimination Against Women (CEDAW). Konvensi ini mengikat negaranegara yang menandatanganinya secara hukum. Tahun 1985, di Nairobi pembicaraan tentang Egality, Development and Peace dan pembicaraan tentang perlunya pembentukan badan yang mampu memecahkan persoalan penggunaan kekerasan jender. Tahun 1993, di Wina, dibicarakan tentang kekerasan terhadap perempuan dan lahirnya persetujuan tentang kekerasan terhadap perempuan merupakan pelanggaran terhadap Hak Asasi manusia serta menyarankan kepada negara-negara anggota untuk menghilangkan kekerasan berdasarkan pasal 1 dari deklarasi dan pasal 2 dari Deklarasi HAM. ${ }^{20}$ Tahun 1995, di Beijing, tahun 1999 sidang khusus PBB, Juni 2000, di New York dibicarakan tentang Gender, egality, development and peace for 21 st century.

Secara historis perjuangan HAM dalam konteks dunia berproses dalam 3 tahap yaitu: pertama, penegakan hak-hak sipil dan politik, dengan ciri orientasi kemerdekaan individu (artikel 2-21 Deklarasi HAM). Kata kunci yang penting adalah usaha menghapus tiap bentuk pengoyakan kemerdekaan manusia dari manipulasi kuasa. Kedua, menegakkan hak-hak ekonomis, sosial dan budaya, dimana negara harus campur tangan untuk menjamin dipenuhinya hak untuk mendapat pekerjaan yang adil, hak untuk hidup sejahtera dari warganya (artikel 22-27 Deklarasi HAM) sebagai anggota keluarga maupun masyarakat. Berorientasi pada kebutuhan dasar manusia. Ketiga, penegakan hak-hak dasar

${ }^{20}$ Pasal 1, berbunyi, "Kekerasan terhadap perempuan adalah tindakan berdasarkan perbedaan jenis kelamin, yang berakibat atau mungkin berakibat kesengsaraan atau penderitaan perempuan secara fisik, seksual atau psikologis, termasuk ancaman tindakan tertentu, pemaksaan atau perampasan kemerdekaan secara sewenang-wenang, baik yang terjadi di depan umum atau dalam kehidupan pribadi. Pasal 2, membagi kekerasan terhadap perempuan dalam 3 kelompok yaitu: kekerasan dalam keluarga, dalam masyarakat luas dan kekerasan yang dilakukan atau dibenarkan oleh negara." 
solidaritas dengan bangsa-bangsa lain, karena kesadaran keterkaitan dalam hidup bersama dalam tanggungjawab ekologi dan sumber-sumber kehidupan dan kesejahteraan bersama. Pada tahap ini pula muncul dua arus gerakan perempuan sebagai aksi pemerdekaan dan reaksi terhadap konstruksi patriakhi emansipasi dan feminisme). ${ }^{21} \mathrm{Jadi}$, dalam perkembangannya diakui bahwa kekerasan terhadap perempuan merupakan pelanggaran terhadap hak asasi manusia. Dengan adanya upaya penghapusan diskriminasi dan kekerasan terhadap perempuan, maka martabat perempuan dipulihkan sebagai manusia yang memiliki kebebasan untuk hidup dengan aman dan bahagia. ${ }^{22}$

\section{Pelaksanaan HAM di Indonesia}

Sebagai salah satu anggota PBB yang ikut menyetujui dan menandatangani konvensi wanita dan Hak-Hak Anak serta deklarasi mengenai kelangsungan hidup, perlindungan dan pengembangan anak, Indonesia telah meratifikasi konvensi tersebut dalam UU nomor 7 Tahun 1984 dan diundangkan di Jakarta tanggal 24 Juli 1984. Dimana penanggung jawab pelaksanaan konvensi tersebut adalah Kementrian Negara Urusan Peranan Wanita dan UU nomor 4 Tahun 1979. Bahkan bila ditarik mundur, dalam Mukadimah UUD 45 telah memuat tentang penghargaan terhadap Hak-hak Asasi Manusia. Namun sampai sejauh ini, pelaksanaan HAM secara keseluruhan maupun secara khusus yang terkait dengan penolakan kekerasan terhadap perempuan masih mengalami hambatan.

Tidak terlaksananya DUHAM dan konvensi-konvensi yang dihasilkan kemudian disebabkan oleh berbagai hal, antara lain: pertama, adanya ketegangan antara HAM universal dan situasi lokal yang berbeda. Pelaksanaan HAM universal tidak dapat dilakukan secara seragam di tingkat lokal karena masing-masing tempat mempunyai adat, nilai-nilai masyarakat yang berbeda, sehingga perlu penyesuaian begitu rupa. ${ }^{23} \mathrm{Hal}$ ini merupakan pergumulan dunia ketiga berhadapan dengan negara-negara adi kuasa. Bahkan kadang kala HAM universal dianggap tidak cocok dengan nilai-nilai yang ada di Asia. ${ }^{24}$ Namun

${ }^{21}$ Sutrisno, "Beberapa Bingkai Wacana Hak Asasi Manusia Dan Visi Pemerdekaan Perempuan."

${ }^{22}$ Maria Silvya E. Wangga and R. Bondan Agung Kardono, "Alternatif Penyelesaian Kekerasan Terhadap Perempuan," ADIL: Jurnal Hukum 9, no. 2 (2019): 78.

${ }^{23}$ Adeney-Risakotha, "Reformasi Gereja Dan HAM Orientasi Baru."

${ }^{24}$ W. Wibisono, "HAM Sebagai Isu Internasional: Memperhatikan Kasus Cina," in Orientasi Baru, Hak Asasi Manusia: Tantangan Bagi Agama (Yogjakarta: Kanisius, 1998), 1926. 
bagi Adnan Buyung Nasution, pemikiran partikularistik seperti itu hanya merupakan arogansi kultural belaka, karena dibalik itu semua sebenarnya ada kepentingan-kepentingan struktural penguasa dan pragmatisme ekonomi Pembangunan yang diprogramkan oleh penguasa dan kroni-kroninya yang ditunjang oleh budaya KKN. Menurut Nasution, kondisi khusus (lokal) tidak berarti membuka peluang untuk mengingkari prinsip-prinsip dasar HAM universal, karena kondisi khusus tersebut juga bersifat dinamis. ${ }^{25}$ Kedua, hukum, sebagai instrumen penegakan HAM memiliki keterbatasan karena hukum adalah hasil pergulatan kepentingan (sosial, ekonomi, politik) dan mencerminkan standart nilai yang dianut oleh masyarakat yang menciptakannya. ${ }^{26}$ Jadi karena adanya pergulatan kepentingan dan lahir dari budaya Patriakhi, maka hukum di Indonesia bermuka ganda dan pada akhirnya melahirkan kekerasan, eksploitasi dan diskriminasi terhadap perempuan. ${ }^{27}$ Ketiga, rendahnya upaya sosialisasi yang dilakukan oleh pihak pemerintah, sehingga persoalan HAM hanya menjadi wacana bagi kelompok intelektual yang jumlahnya lebih sedikit dibandingkan dengan jumlah penduduk Indonesia yang berhak mengetahui dan memperjuangkan HAM di Indonesia. Dengan demikian, pelaksanaan HAM di Indonesia masih merupakan persoalan panjang yang perlu diperjuangkan dengan kesungguhan karena hambatan-hambtan yang ada haruslah diatasi. Diperlukan keberanian untuk melakukan transformasi dalam berbagai aspek kehidupan, sehingga budayapun benar-benar bersifat dinamis.

\section{Gereja dan HAM}

Bila dilihat kembali sejarah munculnya gagasan tentang HAM, Gereja (Gereja Baptis, Kongregasionalis, kelompok Bebas dan golongan Puritan) telah memulai lebih dahulu baik pemahaman maupun praktik kehidupan yang menegakkan HAM. Jadi penegakan HAM bukan sesuatu yang asing bagi Gereja, tetapi merupakan bentuk kesaksian gereja di tengah dunia pada saat itu, sesuai dengan penghayatan iman kepada Allah di dalam Yesus Kristus. Selanjutnya, gereja-gereja yang tergabung dalam WCC (terbentuk pada tahun

${ }^{25}$ Peter B., P. Van Dijk, and A.B. Nasution, Instrumen Internasional Pokok Hak-Hak Asasi Manusia (Jakarta: Yayasan Obor Indonesia, 1997), xxi-xxiv.

${ }^{26}$ Nursyahbani Katjasungkana, "Hukum Dan Perempuan Indonesia," in Penghapusan Diskriminasi Terhadap Wanita, ed. Tapi Omas Ihromi, Sulistyowati Irianto, and A.S.Luluhima (Bandung: Alumni, 2000), 78-86.

27 Komnas Perempuan, "Komisi Nasional Anti Kekerasan Terhadap Perempuan," Komnas Perempuan Tahun 2020. 
1948), telah lama menggumuli persoalan HAM dan tetap menempatkan isue tersebut sebagai perhatian utama, karena mereka mengakui bahwa HAM adalah faktor kunci dalam proses perjuangan keadilan, perdamaian dan rekonsiliasi. Penegakan HAM merupakan kesaksian ekumenis yang integral. WCC juga telah melakukan tindakan pembelaan terhadap korban pelanggaran HAM, termasuk perempuan. ${ }^{28}$ Pada tahun 1974 , di Berlin telah dibicarakan tentang kedudukan perempuan di Gereja dan masyarakat. Pada saat itu pula ditentukan sebagai dekade solidaritas Gereja terhadap perempuan, juga diputuskan tentang program mengatasi kekerasan. Dan sejak itulah dalam setiap konferensi masalah perempuan selalu menjadi salah satu topik percakapan, bahkan WCC telah menerbitkan berbagai karangan tentang perempuan. ${ }^{29}$

Sementara itu di Indonesia, Gereja-gereja yang tergabung dalam PGI (dulu DGI) memusatkan perhatian pada persoalan keesaan dan telah memakan waktu yang cukup lama untuk membicarakan persoalan tersebut, di samping persoalan kesaksian dan pelayanan. ${ }^{30}$ Perbedaan PGI dan WCC terletak pada titik berangkatnya. Bila WCC memulai dengan persoalan HAM, PGI memulai dengan persoalan keesaan. Hal ini tidak berarti bahwa PGI sama sekali tidak menyinggung tentang HAM, karena salah satu cara berpartisipasi dan melayani dalam Pembangunan Nasional diungkapkan dengan jalan berpartisipasi meningkatkan harkat dan martabat manusia serta memperjuangkan HAM. ${ }^{31}$ Namun hal itu hanya seputar wacana, sebagaimana refleksi M.Katoppo, pada Ulang Tahun PGI ke 40 yang lalu, bahwa perjuangan HAM yang dilakukan selama ini tidak berakar dalam spiritualitas yang mendalam, sehingga hanya meupakan wacana yang mudah dilupakan dalam praktik kehidupan bergereja. ${ }^{32}$ Hal ini juga diperjelas dengan tidak adanya sikap kritis terhadap pemerintah terkait dengan pelaksanaan KB, Transmigrasi dan ideologi Trilogi Pembangunan. Dibentuknya Komisi wanitapun berada dalam bayang-bayang pemerintah yang menekankan pada sumbangan perempuan terhadap proses Pembangunan Nasional dan Gereja, bukan menyelesaikan persoalan 72-93.

${ }^{28}$ WCC, "Echoes from the Harare Assembly," The Ecumenical Review 51, no. 1 (1999):

${ }^{29}$ G. Gassmann, Documentary History of Faith and Order, 1963-1993 (Geneva: WCC Publications, 1993), 27,101,107.

${ }^{30}$ PGI, Lima Dokumen Keesaan Gereja, Keputusan Sidang RayaXII PGI, Jayapura, 21 30 Oktober 1994 (Jakarta: BPK Gunung Mulia, 1996), 37.

${ }^{31}$ Ibid.

${ }^{32}$ Mariane Katoppo, "Gereja Sebagai Wadah Memperjuangkan Persamaan HAM," in Gerakan Oikumene: Tegar Mekar Di Bumi Pancasila, Buku Peringatan 40 Tahun PGI, ed. J.M. Pattiasina and W. Sairin (Jakarta: BPK Gunung Mulia, 1993), 90-94. 
ketidakadilan dan kekerasan yang telah ramai dibicarakan di lingkup Internasional, di Asia dan di beberapa kelompok masyarakat yang peduli jender di Indonesia. Baru pada tahun 90-an, ada perhatian terhadap ketidakadilan dan kekerasan terhadap perempuan di kalangan teolog perempuan yang belum menyentuh komunitas basis, yaitu gereja-gereja lokal.

Jadi ada kesenjangan antara harapan dan kenyataan, karena gereja-gereja di Indonesia belum mengakui dan menyadari bahwa pelanggaran terhadap HAM (termasuk kekerasan terhadap perempuan) merupakan persoalan yang serius, yang perlu ditanggapi, bukan karena orang lain telah membicarakannya, namun karena hakekat Gereja adalah saksi karya Pembebasan Allah terhadap manusia yang mengalami penderitaan.

\section{Dasar Teologis Penegakan HAM perempuan}

Untuk mencari pijakan Teologis dalam menanggapi masalah di atas, penulis merasa perlu terlebih dahulu memperhatikan narasi dari Hakim-hakim 19 yang dapat dipakai sebagai cermin dalam memandang realita masa kini sekaligus mengajak gereja untuk melakukan pertobatan. ${ }^{33}$ Setelah itu memperhatikan salah satu hukum sosial yang menjadi landasan bagi Israel untuk bersikap terhadap kelompok masyarakat yang rentan kekerasan sosial, ekonomi, yang sekaligus menjadi salah satu syarat perjanjian antara Israel dan YAHWEH yang harus dipenuhi, yaitu Ulangan 24: 17-22. Dari sini penulis hendak membuktikan bahwa panggilan untuk membebaskan mereka yang tertindas oleh kekerasan struktural ini tetap berlaku pada masa kini dan merupakan tanggung jawab gereja. Terakhir, penulis mengajak gereja untuk belajar dari narasi Yohanes 8: 2-11 yang memperlihatkan sikap Yesus terhadap manusia perempuan yang mengalami kekerasan sosial budaya, sekaligus melihat pembelaan yang dilakukan Yesus tanpa mengabaikan adanya dosa dalam diri manusia.

\section{Hakim-Hakim 19}

Narasi ini berkisah tentang seorang Lewi dan gundiknya. Narasi ini diawali dengan perjalanan seorang Lewi, dari pegunungan Efraim menuju ke Betlehem, rumah ayah dari gundiknya. Dari episode pertama yang mengisahkan perjalanan Lewi hingga berada di rumah mertuanya, narator menggambarkan tentang perbedaan pokok antara ke dua tokoh utama tersebut, yaitu Lewi dan

\footnotetext{
${ }^{33}$ Phyllis Trible, Texts of Terror (Philadelphia: Fortress Press, 1984), 2.
} 
gundiknya. Secara status sosial Lewi jauh lebih terhormat, punya kedudukan di masyarakat, sekaligus ia adalah pemilik/ tuan dari gundik tersebut. Sedangkan gundik, adalah pihak inferior, yang tidak memiliki status sosial tersendiri bila dilepaskan dari ayahnya atau tuannya, ia lebih rendah dari perempuan lain, lebih tepat dikatakan sebagai budak, yang tidak berdaya karena menjadi milik tuannya. Hal ini diperlihatkan dengan jelas, bagaimana kekuasaan Lewi dan ayah gundik tersebut atas diri gundik tak bernama itu. Dan bagaimana gundik tersebut menggambarkan karakter budak perempuan yang sungguh tidak berdaya dan menerima kekeradaannya begitu saja. Selanjutnya dalam episode kedua, diceritakan tentang perjalanan mereka kembali ke pegunungan Efraim, yang terpaksa harus bermalam di Gibea karena hari telah menjelang malam. Mereka diterima oleh seorang tua yang juga berasal dari pegunungan Efraim, namun menetap di Gibea, kota orang Benyamin. Dalam episode inilah terjadi tragedi bagi gundik perempuan tak bernama itu dan seorang anak perempuan dari pemilik rumah tersebut yang masih perawan. Mereka berdua dikorbankan demi keamanan Lewi, oleh pemilik rumah tersebut, ketika ada permintaan dari orang-orang Gibea agar Lewi tersebut diserahkan kepada mereka. Kedua perempuan itu menjadi korban kekuasaan laki-laki (pemilik rumah, Lewi dan orang-orang Gibea) dan korban kekerasan seksual. Mekanisme mengorbankan perempuan agaknya merupakan hal yang lazim karena perempuan adalah milik laki-laki, dalam budaya patriakhi. Jadi status dan keberadaan perempuan ditentukan oleh laki-laki. Penderitaan yang dialami oleh gundik tak bernama itu tidak hanya berhenti dalam episode ini, namun dilanjutkan dalam episode ke tiga, dimana dalam situasi tidak berdaya,${ }^{34}$ ia tidak mendapatkan perlindungan dari tuannya, malah sesampainya di rumah, ia dibantai oleh tuannya, yang semula menjemputnya. Sekali lagi narasi ini memperlihatkan kekejaman yang dialami oleh gundik perempuan, yang dilakukan oleh orang dekatnya.

Narasi yang sangat memilukan ini hendak memperlihatkan pada pembacanya sebuah realita, dimana ketika perempuan ditempatkan secara tidak adil (sebagai milik-obyek) oleh laki-laki dalam struktur sosial budaya patriakhi, pada saat itulah perempuan menjadi korban kekuasaan dan kekerasan secara menyeluruh. Ketidakadilan itu telah melahirkan dehumanisasi perempuan. Perempuan tidak memiliki harkat dan nilai sebagai manusia yang memiliki hak untuk hidup, hak atas dirinya sendiri (termasuk terhadap organ seksualnya), hak

${ }^{34}$ dalam hal ini ada dua penafsiran, yang satu mengatakan sudah mati, yang lain mengatakan masih hidup. Penulis setuju dengan pendapat yang mengatakan bahwa gundik tersebut masih hidup, namun dalam situasi yang sangat lemah dan tidak berdaya. 
untuk hidup dengan aman, adil dan sejahtera, sebagaimana layaknya subyek dalam kehidupan bersama. Selain itu juga diperlihatkan bahwa antara struktur sosial budaya yang tidak adil dan karakter terjadi proses ketergantungan yang melestarikan struktur tersebut. Lalu, dari narasi ini, diminta lahir perenungan mendalam, bahwa pembaca harus memperhatikan dan mempertimbangkan kembali tragedi tersebut dan melakukan sesuatu dari hasil perenungan tersebut. Inilah cermin yang membawa manusia masa kini menyadari adanya situasi yang tidak jauh berbeda pada masa kini, sehingga perlu melahirkan sikap pertobatan, bila selama ini menganggap situasi ketidakadilan dan kekerasan terhadap perempuan bukan masalah serius yang harus ditanggapi, karena adanya struktur sosial budaya patriakhi yang telah membentuk manusia begitu rupa. Berangkat dari pertobatan itulah diharapkan adanya pemahaman dan kehidupan baru yang lebih baik, lebih adil bagi lak-laki dan perempuan. ${ }^{35}$

\section{Ulangan 24:17-22}

Dalam konstruksi budaya patriakhi, perempuan ditempatkan sebagai warga kelas dua yang sejajar dengan anak dan harta kekayaan, yang dimiliki oleh laki-laki. Bila seorang perempuan menjadi janda (mungkin karena suaminya meninggal dalam peperangan atau dalam perbudakan), maka ia tidak memiliki status sosial, kecuali ia memiliki anak laki-laki. Karena ia berada dalam situasi sosial yang sangat rendah, maka ia tidak memiliki akses dalam dunia perekonomian. Pada akhirnya, banyak janda yang bekerja sebagai buruh harian (kecuali janda yang cukup kaya) dan menggantungkan hidupnya pada upah harian yang diterimanya. Bila ia tidak mendapatkan upah, ia masuk pada lingkaran hutang melalui sistem gadai yang berlaku pada masa itu dan apabila ia tidak mampu melunasi hutangnya, maka ia dijadikan budak oleh pemberi hutang. Dari sini kita melihat bahwa janda adalah salah satu dari kelompok masyarakat yang rentan penindasan dan kekerasan, sama dengan anak-anak dan orang asing yang tidak mempunyai status sosial dalam masyarakat pada waktu itu. Untuk mempertahankan kehidupan, mereka harus bekerja keras, tanpa perlindungan yang memadai. ${ }^{36}$

35 Merlin Brenda Angeline Lumintang, "Suara Sang Subaltern: Sebuah Narasi Autobiografi Perempuan Tanpa Nama Dalam Hakim-Hakim 19," DUNAMIS: Jurnal Teologi dan Pendidikan Kristiani 5, no. 2 (2021): 261-277.

36 Triana Sofiani, "Perlindungan Hukum Pekerja Perempuan Sektor Informal," Muwazah 9, no. 2 (2017): 9. 
Bila Israel mendapat perintah untuk tidak menodai hak mereka sebagai manusia, maka perintah ini sangat positif, karena merupakan bentuk perlindungan terhadap mereka yang tidak memiliki perlindungan selama ini. Perintah ini juga memberi kemungkinan bagi mereka untuk hidup secara aman dan terjamin kebutuhan dasarnya. Dengan kata lain Perintah tersebut mengajarkan dan menuntut Israel untuk membebaskan mereka dari keterpurukan sosial, budaya dan ekonomi, sehingga mereka dapat hidup sebagai manusia seutuhnya. Adapun landasan teologis dari perintah tersebut adalah pengalaman pembebasan yang dilakukan YAHWEH terhadap Israel, ketika Israel menjadi budak di Mesir dan diperlakukan secara tidak manusiawi. Karena YAHWEH telah membebaskan Israel, maka Israel pun harus membebaskan sesamanya (termasuk orang asing yang menumpang), yang menjadi korban kekerasan struktural. Secara tidak langsung diungkapkan pula bahwa YAHWEH tidak menghendaki terjadinya kekerasan struktural yang mengakibatkan penderitaan bagi mereka yang lemah (termasuk perempuan), yang disingkirkan. ${ }^{37}$

Dari Ul.24:17-22 ini, pembaca diingatkan akan karya pembebasan yang telah dilakukan oleh YAHWEH pada diri semua manusia, yang harus juga dilanjutkan dalam kehidupan masyarakat yang dikehendaki oleh YAHWEH. Kekerasan struktural melahirkan penderitaan, oleh sebab itu harus ditiadakan. Dan hal ini merupakan tanggung jawab iman setiap orang yang menyambut karya pembebasan YAHWEH.

\section{Yohanes 8: 2-11}

Pemahaman bahwa dalam kasus perzinahan maka perempuan melanggar hukum Taurat dan laki-laki yang melakukan perzinahan bersama perempuan tersebut bebas dari tuntutan hukum Taurat adalah hal yang umum berlaku pada masa Yesus hidup. Itu sebabnya, kasus tersebut dapat dipakai sebagai alat untuk menjebak Yesus yang menyatakan diri sebagai Allah yang menjadi manusia, air sumber kehidupan. Tindakan diskriminasi terhadap perempuan tersebut merupakan bentuk kekerasan terhadap perempuan yang disahkan oleh institusi keagamaan yang berlaku dalam kehidupan masyarakat Yahudi. ${ }^{38}$ Adalah

\footnotetext{
${ }^{37}$ Myrto Theocharous, "Refugee Asylum: Deuteronomy's 'Disobedient' Law," Studies in Christian Ethics 30, no. 4 (2017): 464-474.

${ }^{38}$ Rose Mukansengimana-Nyirimana and Jonathan A. Draper, "The Peacemaking Role of the Samaritan Woman in John 4:1-42: A Mirror and Challenge to Rwandan Women,"

Neotestamentica 46, no. 2 (2012): 299-318.
} 
menarik untuk mencermati sikap Yesus yang tidak terprovokasi oleh ahli-ahli Taurat, orang - orang Farisi dan masyarakat umum. Yesus memperlihatkan sikap yang tegas dalam proses penghakiman tersebut, bahwa ia menentang kekerasan yang dilakukan hanya terhadap perempuan yang berzina. Yesus menegaskan bahwa tidak ada seorang pun yang tidak berdosa, melalui perkataan yang kontroversial (ayat 7). Hal ini mengingatkan pada ungkapan H.R. Niebuhr, bahwa semua kepentingan manusia dinodai oleh dosa. ${ }^{39}$ Jadi bukan hanya perempuan itu saja yang berdosa, tetapi laki-laki yang bersamanya, mereka yang menangkap kedua orang yang berzina itu bahkan mereka yang merekayasa penangkapan tersebut dan yang menciptakan hukum yang tidak adil itu pun berdosa. Yesus tidak mengingkari adanya dosa dalam diri pelaku dan korban kekerasan, namun demikian tindakan sewenang-wenang terhadap perempuan itu adalah persoalan yang serius. Yesus menempatkan harkat, martabat dan status perempuan itu sejajar dengan laki-laki yang ada disekitarnya saat itu. Ia juga manusia yang sama nilai kemanusiaannya dengan yang lain, sesamanya, bukan benda atau obyek yang dapat diperlakukan apa saja menurut kemauan manusia. Sekaligus Yesus membangkitkan kesadaran akan keberadaan perempuan tersebut sebagai subyek dalam kehidupan yang tidak perlu berbuat dosa lagi. ${ }^{40}$

Jadi ada empat sikap yang diperlihatkan Yesus melalui narasi ini, yang pertama, Yesus menyadarkan bahwa setiap manusia berdosa (laki-laki maupun perempuan) dan memiliki kemungkinan yang sama untuk bertobat dan hidup baru. Kedua, Yesus menentang ketidak adilan (termasuk dalam hukum) yang melahirkan kekerasan terhadap perempuan, sekalipun itu berasal dari rahim institusi agama. Ketiga, Yesus memulihkan harkat dan martabat perempuan yang menjadi korban kekerasan tersebut menjadi manusia seutuhnya, yang memiliki hak untuk hidup bebas dari tekanan struktur yang tidak adil. Keempat, Yesus membela perempuan yang menjadi korban kekerasan tersebut dengan kesungguhan.

Dari sikap Yesus inilah, pembaca diminta untuk secara kritis mengenali diri dan masyarakatnya (termasuk struktur dan instrumen kekuasaan yang berlaku), kemudian melakukan perubahan ke arah yang lebih positif sehingga tidak terjadi tindak kesewenang-wenangan yang menodai harkat dan martabat perempuan, yang adalah sesama bagi laki-laki. Dengan demikian kehidupan

${ }^{39}$ C. Fred Alford, "Niebuhr, Evil, and the Holocaust," Open Journal of Political Science 04, no. 01 (2014): 16-22.

${ }^{40}$ Firman Panjaitan, "Ekualitas Antara Laki-Laki Dan Perempuan: Upaya Mereduksi Kekerasan Secara Domestik," Thronos: Jurnal Teologi Kristen 1, no. 2 (2020): 58-72. 
yang lebih adil memungkinkan perempuan mengisi kehidupannya dalam suasana yang baru. Ada rekonsiliasi dan pembaharuan dalam kehidupan bersama.

\section{Sumbangan Gereja-gereja di Indonesia dalam Perjuangan Menegakkan HAM bagi Perempuan yang Menjadi Korban Kekerasan.}

Bonhoeffer mengungkapkan bahwa gereja berada dalam satu realitas dunia yaitu realitas Kristus, dengan demikian maka gereja-gereja di Indonesia harus mengungkapkan kesetiaannya sebagai murid Kristus dalam kehidupan bersama. ${ }^{41}$ Sebagai murid Kristus, gereja harus bersikap kritis terhadap pemerintah yang diberi kedudukan oleh Kristus dalam 'order pemeliharaan' melalui keberpihakan terhadap korban-korban ketidak adilan. Demikian juga halnya dengan Yoder yang memandang gereja sebagai komunitas kudus yang yang dapat menembus dunia melalui analogi dengan praktik. Praktik ketaatan terhadap Kristus merupakan pemenuhan tugas dan tanggung jawab gereja dalam dunia yang harus dilakukan secara kreatif. ${ }^{42}$ Berangkat dari pemahaman tersebut diatas penulis mengajak gereja untuk kembali menyadari hakekatnya sebagai murid Kristus yang harus memenuhi tanggung jawabnya secara kritis dan kreatif di dalam dunia.

Diawali dengan kesediaan gereja untuk memandang dirinya secara kritis, apakah karakter individu dan gereja selaku komunitas Kristus juga dibentuk oleh struktur sosial budaya patriakhi dan melekat erat di dalamnya. Bila itu yang terjadi, maukah gereja menyadari secara jujur bahwa struktur tersebut telah melahirkan ketidak adilan bagi perempuan, karena dominasi yang dilakukan oleh laki-laki membawa penderitaan. ${ }^{43}$ Selanjutnya, bila gereja telah menyadari hal itu, gereja dituntut untuk hidup dalam pembaharuan struktur sosial budaya dalam bergereja dan berkeluarga, sebagai pemenuhan pertobatan. Perlu adanya pembagian kekuasaan dalam kebersamaan yang mencerminkan kesederajatan laki-laki dan perempuan (sebagai manusia yang sama-sana berdosa dan samasama memiliki kemungkinan untuk hidup baru), sehingga tidak ada lagi hubungan tuan/pemilik/penguasa/subyek dengan hamba/harta milik/yang dikuasai/obyek. Dengan adanya struktur yang lebih adil, dimungkinkan bagi

${ }^{41}$ Dietrich Bonhoeffer, Discipleship, Discipleship, 2003, 47.

${ }^{42}$ John H. Yoder, The Politics of Jesus, Vicit Agnus Noster (Grand Rapids, Michigan: William B. Eerdmans Publishing Company, 1972), 87-88.

${ }^{43}$ Michael Walzer, Spheres of Justice, A Defense of Pluralism and Equality (USA: Basic Books, Inc., 1983), 10,26. 
gereja menciptakan situasi pembebasan bagi setiap orang, tidak ada yang perlu menjadi korban kekerasan. Laki-laki dan perempuan bekerja sama secara adil dan aktif menata kehidupan keluarga dan gereja, misalnya ada kerjasama dalam menunaikan kewajiban rumah tangga, bukan hanya menjadi beban dan tanggung jawab istri saja, adanya saling penghargaan dan penghormatan antara suamiistri, sehingga tidak memungkinkan munculnya kekerasan dalam rumah tangga, perlunya pengangkatan pendeta perempuan tanpa mengabaikan kodratnya, tidak diukur dari standart/ukuran laki-laki dan memperoleh gaji dan pengakuan, serta penghargaan yang sama dengan pendeta laki-laki, peran-peran domestik dalam gereja dilakukan bersama baik oleh laki-laki maupun perempuan.

Selanjutnya, setelah gereja mampu melihat dirinya sendiri secara kritis dan jujur, serta bersedia melakukan perubahan, gereja perlu bersikap kritis terhadap pemerintah dan masyarakatnya, mengenali bentuk-bentuk ketidak adilan dan kekerasan yang dilahirkan oleh struktur sosial, budaya, ekonomi, politik yang ada dalam masyarakat. Mengakui bahwa perlu ada perubahan yang terjadi, yang harus dilakukan oleh pemerintah dan masyarakat Indonesia. Gereja bukan hanya menjadi sekolah dan teladan kebajikan saja, sebagaimana yang diungkapkan oleh Hauerwas namun juga perlu untuk memberikan masukan/kritik terhadap pemerintah yang menurut DUHAM bertanggung jawab terhadap pelaksanaan HAM di wilayahnya, secara damai. ${ }^{44}$ Berangkat dari pemahaman bahwa tindak kekerasan terhadap perempuan adalah dosa, karena menghancurkan harkat dan martabat perempuan, maka gereja perlu untuk membela, memulihkan perempuan yang menjadi korban kekerasan dan mensosialisasikan model kehidupan baru yang membawa pengharapan bagi mereka. ${ }^{45}$ Dari segi hukum, Gereja perlu melakukan usulan perubahan Undang-Undang yang bias gender, merugikan perempuan atau yang bertentangan dengan jiwa HAM melalui perangkat pemerintahan yang ada dan bekerjasama dengan pihak-pihak lain, LSM, kelompok study perempuan, misalnya, yang memiliki kepedulian dan memperjuangkan kehidupan yang menghargai manusia secara utuh, tanpa perbedaan. Dalam bidang perekonomian, gereja juga perlu mendukung dan mengembangkan perjuangan perempuan yang mempunyai tanggung jawab untuk menghidupi keluarganya seorang diri, agar mereka tidak menjadi sasaran

${ }^{44}$ Stanley Hauerwas and William H. Willimon, Resident Aliens (Nashville: Abingdon Press, 1989), 65.

${ }^{45}$ Mennonite-Church, A Working Document for Study and Dialogue, Human Sexuality in The Christian Life Responses from the Mennonite Church and The General Conference Mennonite Church, (1990). 134-137. 
empuk berbagai tindak kekerasan. Dalam bidang budaya, gereja perlu berinteraksi dengan kelompok keagamaan dan kelompok masyarakat dalam kerangka proses transformasi budaya dari budaya patriakhi menjadi budaya yang egaliter, dimana laki-laki- dan perempuan diakui dan dihargai sama tinggi, tidak ada lagi dominasi satu terhadap yang lain.

Sebagai tindakan konkret untuk mereduksi kekerasan terhadap perempuan sebagai bentuk pelanggaran HAM, gereja-gereja di Indonesia harus berani menegaskan ajaran kasih yang radikal dalam kehidupan yang menggambarkan kesejajaran antara laki-laki dan perempuan. ${ }^{46}$ Melalui ajaran kasih yang radikal setiap manusia disadarkan akan fungsi dan kedudukannya selaku laki-laki dan perempuan yang setara dan saling bergantung. Kasih yang radikal mengajarkan gaya hidup Kristus yang lebih mengutamakan kesejahteraan bersama dalam pola hidup egaliter. Apabila dalam kehidupan terjadi kekerasan terhadap perempuan, gereja harus berani untuk bersikap untuk memihak pada perempuan yang menjadi korban kekerasan sekaligus berani untuk menyuarakan suara keadilan dalam kehidupan masyarakat secara nyata dan jelas. Wujud keberpihakan gereja terhadap korban adalah melalui pendampingan terhadap korban untuk menumbuhkan kepercayaan diri korban. Gereja harus memberikan kekuatan kepada perempuan yang menjadi korban kekerasan dengan menumbuhkan kesadaran bahwa kedudukan manusia di hadapan Tuhan adalah sama dan semua manusia adalah gambar dan rupa Allah serta manusia dipandang berharga di mata Tuhan (Yes. 43:4), sehingga tidak ada alasan bagi laki-laki memandang rendah perempuan. ${ }^{47}$ Sebagai langkah konkret, penulis mengusulkan agar setiap komisi yang ada dalam gereja haruslah diisi oleh kaum laki-laki dan perempuan, termasuk komisi perempuan atau komisi laki-laki. Gereja harus menempatkan beberapa laki-laki sebagai anggota komisi perempuan gereja demikian juga sebaliknya; karena melalui penempatan tersebut setiap laki-laki dan perempuan dapat belajar memahami pergumulan lawan jenis mereka sekaligus menempatkan diri mereka dalam kesejajaran. Melalui tindakan ini, laki-laki dan perempuan saling belajar menghormati dan menghargai satu sama lain dalam bingkai kesejajaran.

Dalam ranah pendidikan teologi kepada warga, gereja-gereja di Indonesia harus berani mengadakan perombakan dan penyeimbangan idiom/terminologi

\footnotetext{
${ }^{46}$ Sarah E. Colonna and Dara Nix-Stevenson, "Radical Love: Love All, Serve All," International Journal of Critical Pedagogy 6, no. 1 (2015): 5-25.

${ }^{47}$ Panjaitan, "Kekerasan Terhadap Istri Dalam Lingkup Domestik (Suatu Tinjauan Etis Kristiani Tentang Kekerasan Terhadap Keluarga)". 42-67.
} 
yang berbicara mengenai ketidaksemimbangan kedudukan antara perempuan dan laki-laki. Jika selama ini berkembang idiom mengenai 'perempuan yang berasal dari tulang rusuk laki-laki', maka gereja harus berani menyeimbangkan idiom tersebut dengan menekankan idiom 'laki-laki dilahirkan dari rahim seorang perempuan', dimana proses melahirkan ini yang merupakan kebanggaan dan kebahagiaan seorang perempuan. Dengan menyeimbangkan idiom tersebut, akan muncul pemahaman yang seimbang bahwa, di satu sisi, perempuan berasal dari tulang rusuk laki-laki dan di sisi lain laki-laki berasal dari rahim seorang perempuan. Penempatan idiom ini sepintas kilas kelihatan sangat sepele, namun pada dasarnya idiom memiliki kekuatan yang sangat besar dalam mempengaruhi imajinasi setiap orang (bdk. dengan pengaruh iklan/spanduk yang mampu menggiring orang untuk membeli beberapa produk tertentu). Oleh sebab itu, gereja jangan pernah merasa 'alergi' dengan penciptaan-penciptaan idiom, karena ini adalah cara efektif untuk mempengaruhi warga.

\section{Simpulan}

Bila gereja telah mampu menghayati nilai-nilai baru yang membawa gereja pada kehidupan baru, dimana HAM sungguh-sungguh ditegakkan, menjadi perhatian utama dalam kehidupan di dalam maupun di luar gereja, hal itu berarti gereja telah mewujudkan hakikatnya sebagai murid Kristus, sebagai umat yang bertanggung jawab terhadap perjanjian yang telah dibuat Tuhan dengan manusia. Gereja yang telah mengalami karya pembebasan Kristus akan menumbuhkembangkan kasih radikal yang mengupayakan kesetaraan di antara seluruh manusia. Laki-laki dan perempuan akan hidup dalam kesetaraan, saling menghargai dan selalu sadar bahwa mereka ada dalam hubungan yang saling berkelindan dan membutuhkan satu sama lain. Situasi yang diwarnai dengan kasih radikal ini akan terus menghidupi manusia dan dengan semangat bersama manusia akan memperbaharui dunia dengan didasarkan pada pembaharuan yang dilakukan oleh Kristus.

\section{Daftar Pustaka}

Adeney-Risakotha, Bernard T. "Reformasi Gereja Dan HAM Orientasi Baru."

In Orientasi Baru, Hak Asasi Manusia: Tantangan Bagi Agama. Yogjakarta: Kanisius, 1998.

Alford, C. Fred. "Niebuhr, Evil, and the Holocaust." Open Journal of Political Science 04, no. 01 (2014).

Anggito, Albi, and Johan Setiawan. Metodologi Penelitian Kualitatif. 
Sikap Gereja Menghadapi... (Dwi R. Kusumaningdyah dan Arif W.)

Sukabumi: CV Jejak, 2018.

B., Peter, P. Van Dijk, and A.B. Nasution. Instrumen Internasional Pokok Hak-

Hak Asasi Manusia. Jakarta: Yayasan Obor Indonesia, 1997.

Bonhoeffer, Dietrich. Discipleship. Discipleship, 2003.

Brown, R. McAfee. Religion and Violence. 2nd ed. Philadelphia: The Westminster Press, 1987.

Carmody, Denise L. "Kekristenan Zaman Bapa-Bapa Gereja Dan Abad Pertengahan." In Perubahan Peran Pria Dan Wanita Dalam Gereja Dan Masyarakat, edited by Anne Hommes. Yogyakarta - Jakarta: Kanisius BPK Gunung Mulia, 1997.

Colonna, Sarah E., and Dara Nix-Stevenson. "Radical Love: Love All, Serve All.” International Journal of Critical Pedagogy 6, no. 1 (2015).

Fortune, Marie M. "Violence against Women: The Way Things Are Is Not the Way They Have to Be." In Sexuality and the Sacred: Sources for

Theological Reflection, edited by J.B.Nelson and S.P.Longfellow, 326334. Westminster: John Knox Press, 1994.

Gassmann, G. Documentary History of Faith and Order, 1963-1993. Geneva: WCC Publications, 1993.

Hauerwas, Stanley, and William H. Willimon. Resident Aliens. Nashville: Abingdon Press, 1989.

Herkutanto. "Kekerasan Terhadap Perempuan Dan Sistem Hukum Pidana, Pendekatan Dari Sudut Pandang Kedokteran." In Penghapusan Diskriminasi Terhadap Wanita, edited by Tapi Omas Ihromi, Sulistyowati Irianto, and A.Sudiarti Luluhima. Bandung: Alumni, 2000.

Isherwood, Lisa, and Dorothea McEwan. An A to Z of Feminist Theology. Sheffield: Academic Press, 1996.

Israpil, Israpil. "Budaya Patriarki Dan Kekerasan Terhadap Perempuan (Sejarah Dan Perkembangannya)." Pusaka 5, no. 2 (2017).

Katjasungkana, Nursyahbani. "Hukum Dan Perempuan Indonesia." In

Penghapusan Diskriminasi Terhadap Wanita, edited by Tapi Omas Ihromi, Sulistyowati Irianto, and A.S.Luluhima. Bandung: Alumni, 2000.

Katoppo, Mariane. "Gereja Sebagai Wadah Memperjuangkan Persamaan HAM." In Gerakan Oikumene: Tegar Mekar Di Bumi Pancasila, Buku Peringatan 40 Tahun PGI, edited by J.M. Pattiasina and W. Sairin. Jakarta: BPK Gunung Mulia, 1993.

Komnas Perempuan. "Komisi Nasional Anti Kekerasan Terhadap Perempuan." Komnas Perempuan Tahun 2020. 
Lumintang, Merlin Brenda Angeline. "Suara Sang Subaltern: Sebuah Narasi Autobiografi Perempuan Tanpa Nama Dalam Hakim-Hakim 19." DUNAMIS: Jurnal Teologi dan Pendidikan Kristiani 5, no. 2 (2021).

Mennonite-Church. A Working Document for Study and Dialogue, Human Sexuality in The Christian Life Responses from the Mennonite Church and The General Conference Mennonite Church (1990).

Muhajarah, Kurnia. "Kekerasan Terhadap Perempuan Dalam Rumah Tangga." Sawwa 11, no. 2 (2016).

Mukansengimana-Nyirimana, Rose, and Jonathan A. Draper. "The Peacemaking Role of the Samaritan Woman in John 4:1-42: A Mirror and Challenge to Rwandan Women." Neotestamentica 46, no. 2 (2012).

N., Toeti Heraty. "Etika Sosial Dalam Perspektif Jender." In Etika Politik Dalam Konteks Indonesia, edited by Eddy Kristiyanto. Yogyakarta: Kanisius, 2001.

Panjaitan, Firman. "Ekualitas Antara Laki-Laki Dan Perempuan: Upaya Mereduksi Kekerasan Secara Domestik." Thronos: Jurnal Teologi Kristen 1, no. 2 (2020).

_. "Kekerasan Terhadap Istri Dalam Lingkup Domestik (Suatu Tinjauan Etis Kristiani Tentang Kekerasan Terhadap Keluarga)." Fidei: Jurnal Teologi Sistematika dan Praktika 1, no. 1 (2018).

PGI. Lima Dokumen Keesaan Gereja, Keputusan Sidang RayaXII PGI, Jayapura, 21-30 Oktober 1994. Jakarta: BPK Gunung Mulia, 1996.

Poerwandari, Kristi. "Kekerasan Terhadap Perempuan: Tinjauan Psikologi Feministik." In Penghapusan Diskriminasi Trehadap Wanita, edited by Tapi Omas Ihromi, Sulistyowati Irianto, and A.Sudiarti Luluhima. Bandung: Alumni, 2000.

Silvya E. Wangga, Maria, and R. Bondan Agung Kardono. "Alternatif Penyelesaian Kekerasan Terhadap Perempuan.” ADIL: Jurnal Hukum 9, no. 2 (2019).

Sofiani, Triana. "Perlindungan Hukum Pekerja Perempuan Sektor Informal." Muwazah 9, no. 2 (2017).

Sturm, Douglas, and Glen H. Stassen. Just Peacemaking: Transforming Initiatives for Justice and Peace. Journal of Law and Religion. Vol. 16. Westminster: John Knox Press, 2001.

Susilarti, Esti. “Di Balik Tirai Tabu.” In Rifka Annisa, edited by Esti Susilarti. Yogyakarta: SKH Kedaulatan Rakyat dan Rifka Annisa, 2000.

Sutrisno, Muji. "Beberapa Bingkai Wacana Hak Asasi Manusia Dan Visi 
Sikap Gereja Menghadapi... (Dwi R. Kusumaningdyah dan Arif W.)

Pemerdekaan Perempuan." In Etika Politik Dalam Konteks Indonesia, edited by Eddy Kristiyanto. Yogjakarta: Kanisius, 2001.

Theocharous, Myrto. "Refugee Asylum: Deuteronomy's 'Disobedient' Law."

Studies in Christian Ethics 30, no. 4 (2017).

Trible, Phyllis. Texts of Terror. Philadelphia: Fortress Press, 1984.

Walzer, Michael. Spheres of Justice, A Defense of Pluralism and Equality. USA:

Basic Books, Inc., 1983.

WCC. "Echoes from the Harare Assembly." The Ecumenical Review 51, no. 1 (1999).

Wibisono, W. "HAM Sebagai Isu Internasional: Memperhatikan Kasus Cina."

In Orientasi Baru, Hak Asasi Manusia: Tantangan Bagi Agama. Yogjakarta: Kanisius, 1998.

Yoder, John H. The Politics of Jesus, Vicit Agnus Noster. Grand Rapids, Michigan: William B. Eerdmans Publishing Company, 1972. 